\title{
Phosphoric Acid Dynamics in High Temperature Polymer Electrolyte Membranes
}

Aili, David; Becker, Hans; Reimer, Uwe; Andreasen, Jens Wenzel; Cleemann, Lars Nilausen; Jensen, Jens Oluf; Pan, Chao; Wang, Xingdong; Lehnert, Werner; Li, Qingfeng

Published in:

Journal of the Electrochemical Society

Link to article, DOI:

10.1149/1945-7111/abb70c

Publication date:

2020

Document Version

Peer reviewed version

Link back to DTU Orbit

Citation (APA):

Aili, D., Becker, H., Reimer, U., Andreasen, J. W., Cleemann, L. N., Jensen, J. O., Pan, C., Wang, X., Lehnert, W., \& Li, Q. (2020). Phosphoric Acid Dynamics in High Temperature Polymer Electrolyte Membranes. Journal of the Electrochemical Society, 167(13), [134507]. https://doi.org/10.1149/1945-7111/abb70c

\section{General rights}

Copyright and moral rights for the publications made accessible in the public portal are retained by the authors and/or other copyright owners and it is a condition of accessing publications that users recognise and abide by the legal requirements associated with these rights.

- Users may download and print one copy of any publication from the public portal for the purpose of private study or research.

- You may not further distribute the material or use it for any profit-making activity or commercial gain

- You may freely distribute the URL identifying the publication in the public portal 


\title{
Phosphoric acid dynamics in high temperature polymer
}

\section{electrolyte membranes}

\author{
David Aili ${ }^{1}$, Hans Becker ${ }^{2}$, Uwe Reimer ${ }^{3}$, Jens Wenzel Andreasen ${ }^{1}$, Lars N. Cleemann ${ }^{1}$, Jens \\ Oluf Jensen ${ }^{1}$, Chao Pan ${ }^{1}$, Xingdong Wang, ${ }^{4}$ Werner Lehnert ${ }^{3}$ and Qingfeng $\mathrm{Li}^{1}{ }^{\text {** }}$ \\ 1 Department of Energy Conversion and Storage, Technical University of Denmark, Fysikvej, Building 310, 2800 \\ Lyngby, Denmark, ${ }^{*}$ Corresponding author (E-mail: qfli@dtu.dk) \\ 2 National Physical Laboratory, Teddington, Middlesex, TW11 0LW, United Kingdom \\ 3 Forschungszentrum Jülich GmbH, IEK-14: Electrochemical Process Engineering, 52425 Jülich, Germany \\ 4 State Key Laboratory of Advanced Metallurgy, University of Science and Technology Beijing, 30 College Road, \\ Beijing 100083, China
}

\begin{abstract}
Phosphoric acid doped perfluorosulfonic acid membranes show high ion conductivity at low water activity at temperatures well beyond $100{ }^{\circ} \mathrm{C}$. However, such electrolyte systems can only support currents of a few $\mathrm{mA} \mathrm{cm}^{-2}$. In this work, it is experimentally verified that the current window in fuel cells and hydrogen pumps under dry conditions is limited by the migration of $\mathrm{H}_{4} \mathrm{PO}_{4}{ }^{+}$species in combination with the slow $\mathrm{H}_{3} \mathrm{PO}_{4}$ diffusion. The phosphoric acid dynamics were monitored in a cell equipped with integrated reference electrodes in the electrolyte membrane, which allowed for quantification of the phosphoric acid in different membrane segments. From the time-resolved measurements, the $\mathrm{H}_{4} \mathrm{PO}_{4}{ }^{+}$transference number was found to be as high as $52 \%$ under dry conditions. In combination with the slow $\mathrm{H}_{3} \mathrm{PO}_{4}$ back-diffusion, which was 5-6 orders of
\end{abstract}


magnitude lower than that of water, the migration of $\mathrm{H}_{4} \mathrm{PO}_{4}{ }^{+}$towards the cathode results in rapid resistance increase at the anode-membrane interface, ultimately leading to cell failure.

\section{Introduction}

The high temperature polymer electrolyte membrane fuel cells operating at temperatures of 120$200{ }^{\circ} \mathrm{C}$, as first reported by Wainright et al., ${ }^{1}$ have been intensively developed to a technologically mature stage during the last two decades due to their simpler water management and high impurity tolerance..$^{2-6}$ The research and development in this area have resulted in significant progress in terms of e.g. precious metal loading reduction, ${ }^{7,8}$ durability enhancement ${ }^{9,10}$ and extension of the operational temperature window to beyond $200{ }^{\circ} \mathrm{C}$ to further improve fuel impurity tolerance and govern catalyst kinetics. ${ }^{11-13}$

The cells are typically constructed based on polybenzimidazole (PBI) membranes, doped with phosphoric acid (PA) to a loading of $10-20 \mathrm{H}_{3} \mathrm{PO}_{4}$ molecules per polymer repeat unit. ${ }^{3}, 14$ Such membranes support ion conductivity as high as $50-150 \mathrm{mS} \mathrm{cm}^{-1}$ at temperatures up to 180 ${ }^{\circ} \mathrm{C}$ at very low water activities. ${ }^{15,16}$ Membranes with acid loadings corresponding to $30-40 \mathrm{H}_{3} \mathrm{PO}_{4}$ molecules per polymer repeat unit can support ion conductivities up to $300 \mathrm{mS} \mathrm{cm}^{-1}$ or even higher, but are mechanically weak due to the plasticization imposed by the doping acid. ${ }^{17,18}$

The success of the PA doped PBI membranes as a high temperature polymer electrolyte system is mainly attributed to the high intrinsic ion conductivity of PA at low water activities and the high degree of Grotthuss type structural diffusion proton conduction. ${ }^{19}{ }^{20}$ The predominating Grotthuss-type conductivity was confirmed by the high proton $\left(\mathrm{H}^{+}\right)$transference number, ${ }^{21}$ but it was more recently shown to prevail in a rather narrow temperature and composition range around $100 \% \mathrm{H}_{3} \mathrm{PO}_{4}{ }^{22,}{ }^{23}$ Addition of water toward the low concentration region $(<100 \%)$ promotes the 
acid dissociation, which results in higher conductivity due to increased contribution from the vehicular mechanism of the proton conduction. On the higher concentration region $(>100 \%)$ dehydration of the acid also leads to increased contribution of vehicular conduction due to the formation of additional phosphoric oxoacid charge carriers, such as $\mathrm{H}_{3} \mathrm{P}_{2} \mathrm{O}_{7}^{-}, \mathrm{H}_{2} \mathrm{P}_{2} \mathrm{O}_{7}^{2-}$ or $\mathrm{H}_{3} \mathrm{P}_{3} \mathrm{O}_{10}{ }^{2-}$ from acid condensation. ${ }^{23,} 24$ The presence of a basic polymer, e.g. PBI, further promotes the acid dissociation, due to the nearly quantitative formation of a protic polybenzimidazolium with $\mathrm{H}_{2} \mathrm{PO}_{4}^{-}$ as the counter-anion, as shown in Scheme 1 (top). ${ }^{20,25-28}$ However, under typical fuel cell operating conditions the anion transference number remains $1-4 \%$, which is similar to that of pure PA. ${ }^{29}$

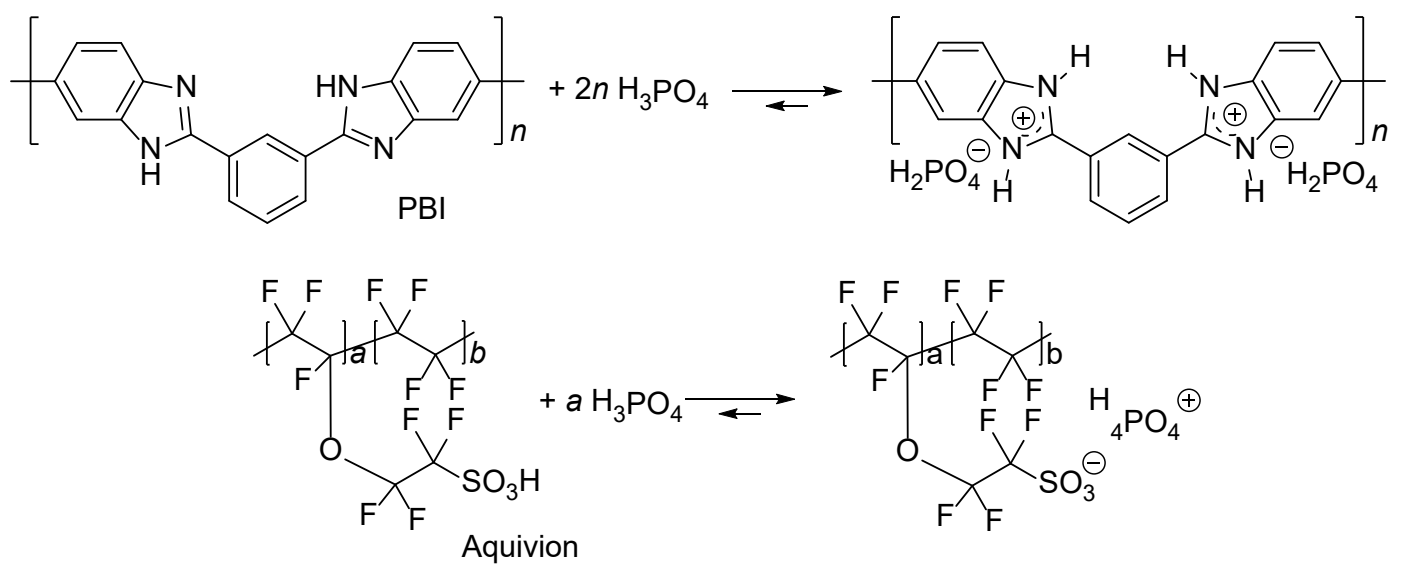

Scheme 1 The acid-base equilibrium between PBI (top) or Aquivion (bottom) and nominally dry $\mathrm{H}_{3} \mathrm{PO}_{4}$.

From a technological point of view in connection to fuel cell operation and durability, the parasitic migration and electroosmotic drag of phosphoric oxoacid species due to the contribution from vehicular conduction is problematic. Under certain operating conditions, it may result in the development of severe PA redistribution and imbalance, as evidenced by advanced in-operando imaging $^{30-32}$ as well as electrochemical methods. ${ }^{29,33}$ 
Before the success with PA doped PBI, PA doped perfluorosulfonic acid (PFSA) membranes were explored as a high temperature polymer electrolyte membrane system. ${ }^{34}$ The membrane was shown to support high conductivity of $20 \mathrm{mS} \mathrm{cm}^{-1}$ at temperatures up to $175^{\circ} \mathrm{C}$, and has proven successful in steam electrolysis applications. ${ }^{35-38}$ However, no successful fuel cell test data have been reported in the literature. As suggested in our previous work, ${ }^{39}$ the malfunction of the fuel cell is connected to anode failure due to a sudden increase of the resistance at the membrane-electrode interface at a current density of around $50 \mathrm{~mA} \mathrm{~cm}{ }^{-2}$. It was hypothesized that the sudden increase of the anode resistance was connected to the migration of the phosphacidium $\left(\mathrm{H}_{4} \mathrm{PO}_{4}{ }^{+}\right)$cation, which was expected to form under dry conditions through protonation of $\mathrm{H}_{3} \mathrm{PO}_{4}$ (in this context a Brønsted base) by PFSA as shown in Scheme 1 (bottom). ${ }^{40,41}$ The interpretation of the results was that the $\mathrm{H}_{4} \mathrm{PO}_{4}{ }^{+}$cation migrated from the anode towards the cathode via the vehicular proton conduction, and the slow back-diffusion of the formed acid resulted in acid depletion at the anode-membrane interface.

In this work, the ohmic response of a hydrogen pump cell constructed based on a segmented PA doped PFSA membrane with integrated reference electrodes is explored. The work provides new insight that further supports the hypothesis that the malfunction is connected to $\mathrm{H}_{4} \mathrm{PO}_{4}{ }^{+}$ migration, as proposed in our previous work. ${ }^{39}$ Furthermore, the time resolved measurements were used to calculate the $\mathrm{H}_{4} \mathrm{PO}_{4}{ }^{+}$transference number in PA doped PFSA along with the diffusion coefficient of $\mathrm{H}_{3} \mathrm{PO}_{4}$.

\section{Experimental}

\subsection{Materials}


The PFSA membranes used were Aquivion ${ }^{\circledR} 79-05 S$ (Solvay), which is a chemically stabilized short-side-chain PFSA membrane with an equivalent weight of $790 \mathrm{~g}^{\text {eq. }}{ }^{-1}$ and a nominal dry thickness of $50 \mu \mathrm{m}$. After pretreatment in aqueous $\mathrm{H}_{2} \mathrm{O}_{2}\left(3 \mathrm{wt} \%, 80{ }^{\circ} \mathrm{C}, 1 \mathrm{~h}\right), \mathrm{H}_{2} \mathrm{SO}_{4}\left(0.5 \mathrm{~mol} \mathrm{~L}^{-1}\right.$, $80{ }^{\circ} \mathrm{C}, 1 \mathrm{~h}$ ) and pure demineralized water at $80-90^{\circ} \mathrm{C}$ for $2 \mathrm{~h}$, membrane samples of $5 \times 5 \mathrm{~cm}^{2}$ area were prepared and immersed in 50-95 wt.\% aqueous $\mathrm{H}_{3} \mathrm{PO}_{4}$ (Sigma-Aldrich) contained in a capped bottle, which was then kept in a heating cabinet at $120-180{ }^{\circ} \mathrm{C}$ for $16 \mathrm{~h}$. The PA uptake was calculated gravimetrically based on the weight increase. The corresponding acid doping level (ADL), i.e. the number of $\mathrm{H}_{3} \mathrm{PO}_{4}$ molecules per sulfonic acid group, was calculated according to Equation 1, where $m_{\text {undoped }}$ and $m_{\text {doped }}$ is the mass before and after doping, respectively, $c$ is the weight fraction of $\mathrm{H}_{3} \mathrm{PO}_{4}$ with respect to water in the membrane phase (assumed to be the same as in the doping solution), $M$ is the molar mass of $\mathrm{H}_{3} \mathrm{PO}_{4}\left(98 \mathrm{~g} \mathrm{~mol}^{-1}\right)$ and $E W$ is the equivalent weight of Aquivion ${ }^{\circledR} 79-05 \mathrm{~S}$ (790 g per mol - $\left.\mathrm{SO}_{3} \mathrm{H}\right)$.

$\mathrm{ADL}=\left(\left(\left(m_{\text {doped }}-m_{\text {undoped }}\right) \times c\right) / M\right) /\left(m_{\text {undoped }} / E W\right)$

The volume swelling was calculated based on the volumes before and after doping. The membrane thickness was taken as an average of 8 measurements. The doped membranes were stored in the doping acid at room temperature until use.

The gas diffusion electrodes were prepared by spray coating a catalytic layer on a carbonbased gas diffusion layer with a microporous layer (Freudenberg, H23C2). The ink was prepared by dispersing platinum supported on carbon black (57\% Pt/C, Johnson Matthey HiSpec 9100) in ethanol during ultrasonication for at least $1 \mathrm{~h}$. Thereafter, an ionomer dispersion (Aquivion ${ }^{\circledR}$ D7925BS) was added, and the catalyst ink was then sprayed using an Exacta-Coat spray robot from 
SONO-TEK Corporation. The platinum and ionomer loading of the final electrode was around 0.8 $\mathrm{mg} \mathrm{cm}{ }^{-2}$ and $0.13 \mathrm{mg} \mathrm{cm}^{-2}$, respectively.

\subsection{Methods}

The cells were assembled with a compiled electrolyte consisting of 4 equal layers of PA doped PFSA membranes, with a total thickness of about $280 \mu \mathrm{m}$. The two outermost layers of the membranes were in direct contact with gas diffusion electrodes of $2 \times 2 \mathrm{~cm}^{2}$, which served as the working and counter electrodes. Between each intermediate membrane and the contacting outermost membrane, a micro platinum wire of a diameter of $25 \mu \mathrm{m}$ was placed as indicated in Figure 1 (position B and C). The wires were coated with a $5 \mu \mathrm{m}$ polyimide insulation layer, which was removed by burning off around the tip in order to provide electrical contact with the membranes as a reference electrode.

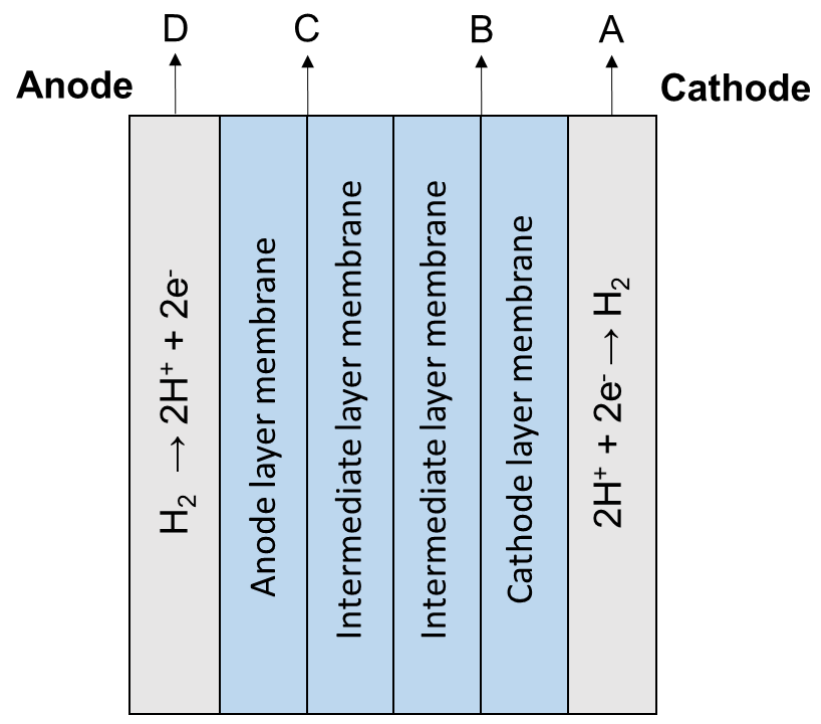

Figure 1 Schematic representation of the layered membrane cell, where A and D represent the two gas diffusion electrodes while $\mathrm{B}$ and $\mathrm{C}$ represent the platinum micro reference electrodes. 
The ohmic resistance of the outermost layer membrane was measured between either A and B or $\mathrm{C}$ and $\mathrm{D}$, i.e. including the gas diffusion electrode.

The gas diffusion electrodes, the sandwiched layered membrane and platinum wires were positioned between two graphite channel plates without prior hot pressing. The assembled cell was thereafter clamped by aluminum endplates with 4 bolts $(6 \mathrm{~mm}$ in diameter) at a torque of $1 \mathrm{Nm}$ and equipped with heating elements and current collectors for temperature control and electrode connection.

The $\mathrm{H}_{2}$ gas was supplied to both sides of the cell at a constant volumetric flow rate of 100 $\mathrm{NmL} \min ^{-1}$. Humidification of the $\mathrm{H}_{2}$ feed was achieved via two in-house built steel evaporators, into which water was provided via an infusion pump (Shimadzu LC-20AD). The evaporators were connected directly to the cell channel plates in order to eliminate any cold spot where condensation of water could occur. The cell was operated at $160^{\circ} \mathrm{C}$ and the water vapor partial pressure $p\left(\mathrm{H}_{2} \mathrm{O}\right)$ was controlled between 0 and $0.8 \mathrm{~atm}$ by the flow rates of water and hydrogen. The temperature of the evaporators was always set to $180^{\circ} \mathrm{C}$.

The cell was operated in hydrogen pumping mode and the current-voltage (I-V) polarization curves were first measured under varied water vapor partial pressures. The I-V curves were recorded at a scan rate of $1 \mathrm{mV} \mathrm{s}^{-1}$, using a VersaSTAT 4 from Princeton Applied Research.

Electrochemical impedance spectroscopy (EIS) was carried out using the same VersaSTAT 4 potentiostat in galvanostatic mode within a typical frequency range from $10^{5}-1 \mathrm{~Hz}$. The duration of each cycle was $10.25 \mathrm{~s}$, which was immediately followed by another cycle in the time-resolved measurements. A current amplitude of $20-50 \mathrm{~mA}$ was applied depending on the water vapor pressure in order to achieve a significant voltage signal and hence a stable EIS signal. The 
resistance of the outermost layer membrane was measured between the platinum microelectrode as reference and a gas diffusion electrode, i.e. between $\mathrm{A}$ and $\mathrm{B}$ or $\mathrm{C}$ and $\mathrm{D}$ in Figure 1. The resistance was taken as $Z_{\text {re }}$ at the high frequency intercept with the $Z_{\mathrm{im}}$ axis. The ohmic resistance contribution of the gas diffusion electrode was observed to be negligible.

The small angle X-ray scattering (SAXS) data were acquired using a rotating anode as Xray source $\left(\mathrm{Cu} \mathrm{K}_{\alpha}\right.$ radiation, $\left.\lambda=1.5418 \AA\right)$, focused and monochromatized by a $2 \mathrm{D}$ multilayer single reflection optic. Three pinholes further collimated the beam to $1 \mathrm{~mm}$ diameter at the sample position. The samples of different PA loadings were placed between two mica sheets $(10 \mu \mathrm{m}$ thickness) in a sample holder that was sealed with an o-ring. The instrument was evacuated from source to detector to minimize air scattering and the isotropic small angle scattering data were acquired by a 2D gas proportional delay line detector ${ }^{42}$ with a pixel size of $0.217 \times 0.207 \mathrm{~mm}^{2}$ at a distance of $1435 \mathrm{~mm}$ from the sample. The 2D data were azimuthally integrated to $1 \mathrm{D}$ scattering cross-sections.

\section{Results and discussion}

\subsection{Phosphoric acid doping}

The PFSA membranes were equilibrated in aqueous $\mathrm{H}_{3} \mathrm{PO}_{4}$ of different concentrations at different temperatures to obtain different $\mathrm{H}_{3} \mathrm{PO}_{4}$ loadings. As summarized in Table 1, the $\mathrm{H}_{3} \mathrm{PO}_{4}$ uptake increased with increasing concentration of the doping solution. After doping in $50 \mathrm{wt} . \% \mathrm{H}_{3} \mathrm{PO}_{4}$ at $120{ }^{\circ} \mathrm{C}$ the $\mathrm{H}_{3} \mathrm{PO}_{4}$ uptake corresponded to an $\mathrm{ADL}$ of around $1.7 \mathrm{H}_{3} \mathrm{PO}_{4}$ per sulfonic acid group, which increased to around $8 \mathrm{H}_{3} \mathrm{PO}_{4}$ per sulfonic acid group after doping in 95 wt. $\% \mathrm{H}_{3} \mathrm{PO}_{4}$ at 180 ${ }^{\circ} \mathrm{C}$. For comparison, the $\mathrm{H}_{3} \mathrm{PO}_{4}$ uptake of Nafion 117 after treatment in 85 wt. $\%$ at $150{ }^{\circ} \mathrm{C}$ corresponds to an ADL of 4-5 $\mathrm{H}_{3} \mathrm{PO}_{4}$ per sulfonic acid group. ${ }^{43}$ It should be remarked that the 
ADLs were calculated from the gravimetric data, based on the assumption that the $\mathrm{PA} /$ water ratio within the membrane phase was the same as in the doping acid.

Table 1 Acid uptake and volume swelling after doping in aqueous PA at different concentrations and temperatures for $16 \mathrm{~h}$. The data are given as the average of 4 repetitions with corresponding standard deviations.

\begin{tabular}{|c|c|c|c|}
\hline Doping conditions & Acid uptake / wt.\% & $\mathrm{ADL} /\left(\mathrm{H}_{3} \mathrm{PO}_{4}\right)\left(-\mathrm{SO}_{3} \mathrm{H}\right)^{-1}$ & Swelling / vol.\% \\
\hline $95 \% \mathrm{H}_{3} \mathrm{PO}_{4}, 180{ }^{\circ} \mathrm{C}$ & $105 \pm 8$ & $8.0 \pm 0.6$ & $106 \pm 7$ \\
\hline $85 \% \mathrm{H}_{3} \mathrm{PO}_{4}, 150{ }^{\circ} \mathrm{C}$ & $66 \pm 1$ & $4.5 \pm 0.1$ & $89 \pm 2$ \\
\hline $65 \% \mathrm{H}_{3} \mathrm{PO}_{4}, 140^{\circ} \mathrm{C}$ & $60 \pm 1$ & $3.2 \pm 0.1$ & $73 \pm 3$ \\
\hline $50 \% \mathrm{H}_{3} \mathrm{PO}_{4}, 120{ }^{\circ} \mathrm{C}$ & $41 \pm 1$ & $1.7 \pm 0.1$ & $54 \pm 3$ \\
\hline
\end{tabular}

The acid uptake was accompanied by volume swelling in the range of around 50-100\% depending on the doping conditions. The SAXS data in Figure 2 showed for the dry undoped Aquivion membrane a characteristic ionomer peak at around $q=2.2 \mathrm{~nm}^{-1}\left(q=\frac{4 \pi \sin \theta}{\lambda}\right.$, where $2 \theta$ is the scattering angle, and $\lambda$ is the $\mathrm{X}$-ray wavelength), corresponding to the hydrophobic/hydrophilic separation in the amorphous regions of the membrane. ${ }^{44}$ For the membranes with $\mathrm{H}_{3} \mathrm{PO}_{4}$ loading corresponding to 1.3-2.2 $\mathrm{H}_{3} \mathrm{PO}_{4}$ per sulfonic acid group, the ionomer peak was shifted to around $q=1.4 \mathrm{~nm}^{-1}$. A broad structure peak at lower $q$ values could also be seen for the undoped and lower doped membranes, likely originating from the crystalline regions ${ }^{44,45}$ Further increasing the $\mathrm{H}_{3} \mathrm{PO}_{4}$ loading to $7.2 \mathrm{H}_{3} \mathrm{PO}_{4}$ per sulfonic acid group shifted the ionomer peak to around $q=1.0$ $\mathrm{nm}^{-1}$. Such a shift is typically observed for PFSA membranes as the degree of hydration increases, and is due to the expansion of the hydrophilic domains within the membranes. ${ }^{46,47}$ Thus, the 
nanostructure of the $\mathrm{H}_{3} \mathrm{PO}_{4}$ doped PFSA is assumed to be analogous to the phase segregated structure that is developed in the presence of pure water, ${ }^{46,48,49}$ suggesting that the PA accumulates in the hydrophilic domains within the membrane.

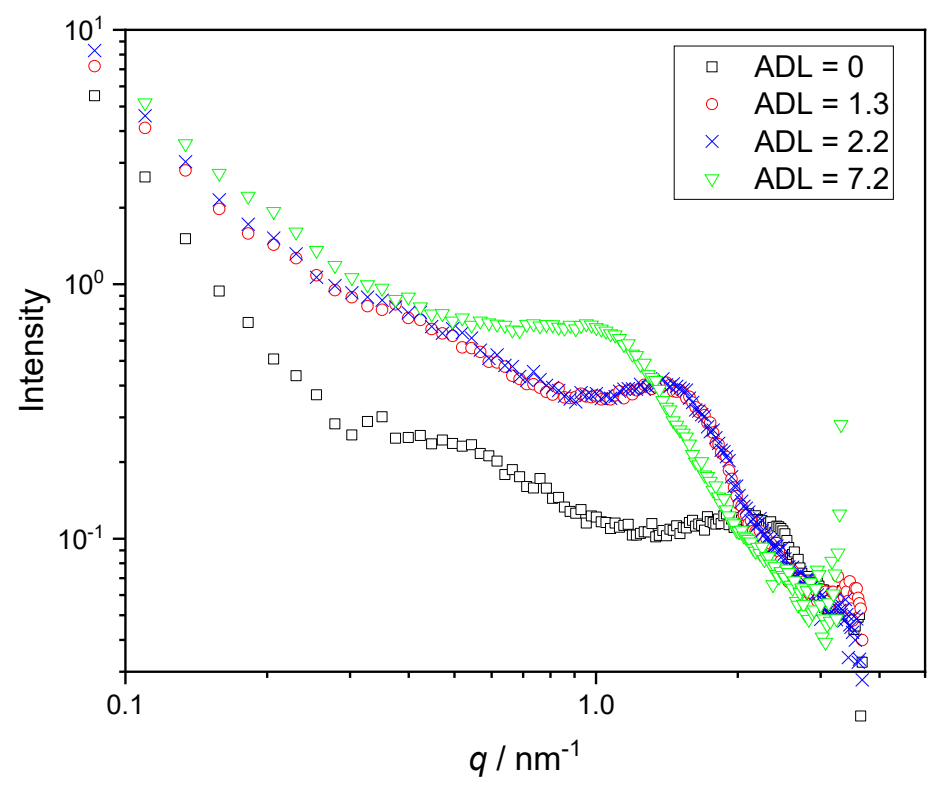

Figure 2 SAXS patterns of Aquivion ${ }^{\circledR} 79-05 \mathrm{~S}$ with an ADL of 0, 1.3, 2.2 and 7.2 $\mathrm{H}_{3} \mathrm{PO}_{4}$ per sulfonic acid group.

\subsection{Response to polarization and humidity changes}

As shown in our previous work, ${ }^{39}$ the malfunction of the PA doped PFSA membrane in fuel cells at current densities above $100 \mathrm{~mA} \mathrm{~cm}^{-2}$ is a consequence of sudden increased ohmic resistance on the anode side. With a hydrogen pumping cell at $120{ }^{\circ} \mathrm{C}$, a limiting current density was observed at approximately $60 \mathrm{~mA} \mathrm{~cm}^{-2} \cdot{ }^{39}$ As shown in Figure 3, the limiting current density under dry, i.e. non-humidified, conditions $\left(p\left(\mathrm{H}_{2} \mathrm{O}\right)=0.0 \mathrm{~atm}\right)$ was reduced to about $30 \mathrm{~mA} \mathrm{~cm} \mathrm{~cm}^{-2}$ when the temperature was further increased to $160^{\circ} \mathrm{C}$. With an increase in the water partial pressure to 0.2 
atm, the limiting current was increased to about $60 \mathrm{~mA} \mathrm{~cm}{ }^{-2}$. At further increased water partial pressures, the limiting current density became less obvious. However, a deviation of the I-V curves from the linear relationship was still noticeable at water partial pressures as high as $0.8 \mathrm{~atm}$.

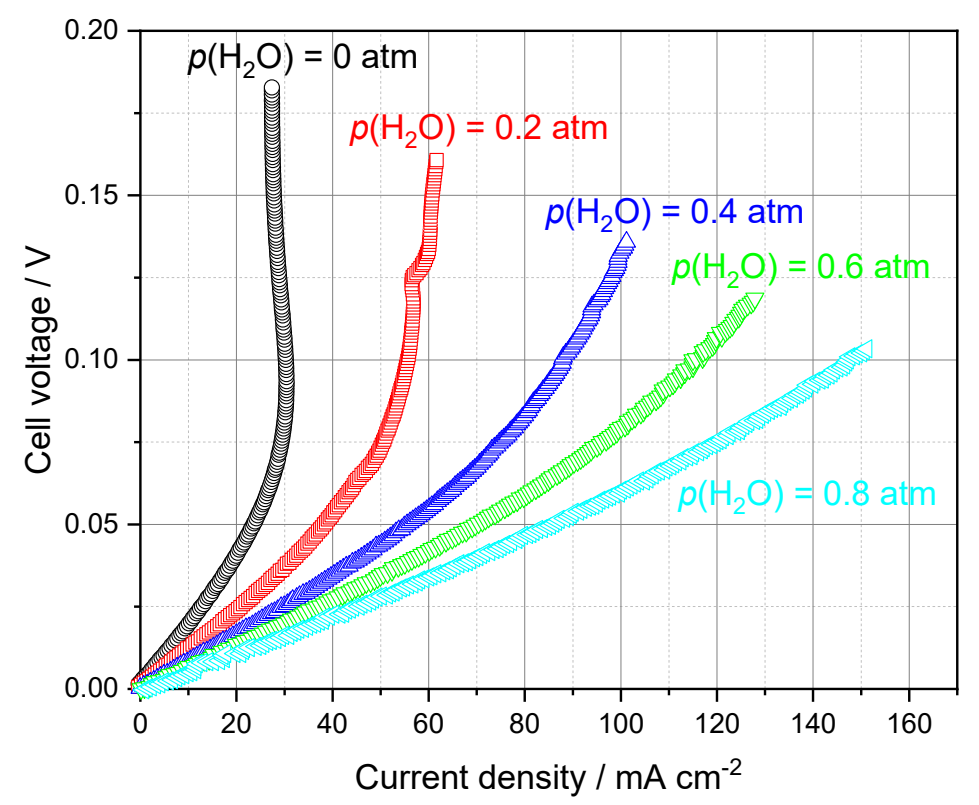

Figure 3 Polarization curves of an entire $\mathrm{H}_{2}-\mathrm{H}_{2}$ cell equipped with four layers of PA doped PFSA membranes under different water partial pressures. The cell temperature was $160{ }^{\circ} \mathrm{C}$ and the scan rate was $1 \mathrm{mV} \mathrm{s}^{-1}$.

Figure 4 shows a set of EIS spectra measured on the anode side membrane, between C to D according to Figure 1 . At $160^{\circ} \mathrm{C}$ and under $p\left(\mathrm{H}_{2} \mathrm{O}\right)=0.8$ atm without applied polarization current. Taking the ohmic resistance as $Z_{\mathrm{re}}$ at $Z_{\mathrm{im}}=0 \Omega \mathrm{cm}^{2}$, the membrane exhibited an area specific resistance of $0.163 \Omega \mathrm{cm}^{2}$, corresponding to a conductivity of $0.043 \mathrm{~S} \mathrm{~cm}^{-1}$. As soon as a constant current density of $150 \mathrm{~mA} \mathrm{~cm}^{-2}$ was applied, the resistance of the anode side membrane started to 
increase, reaching a steady state value of $0.287 \Omega \mathrm{cm}^{2}$ after 20 cycles ( $\left.205 \mathrm{~s}\right)$, as indicated by the blue filled markers in Figure 4. When the current was stopped, the resistance of the anode side membrane started to decrease, as shown in Figure 4 by the series of red unfilled markers. The initial resistance of $0.163 \Omega \mathrm{cm}^{2}$ was restored after 20 cycles. The resistance of the cathode side membrane between A and B was measured as well, but is not shown in the figure for clarity. The resistance changed in the opposite way, i.e. it decreased when a cathode current density of - 150 $\mathrm{mA} \mathrm{cm}{ }^{-2}$ was turned on and then increased when the current was turned off.

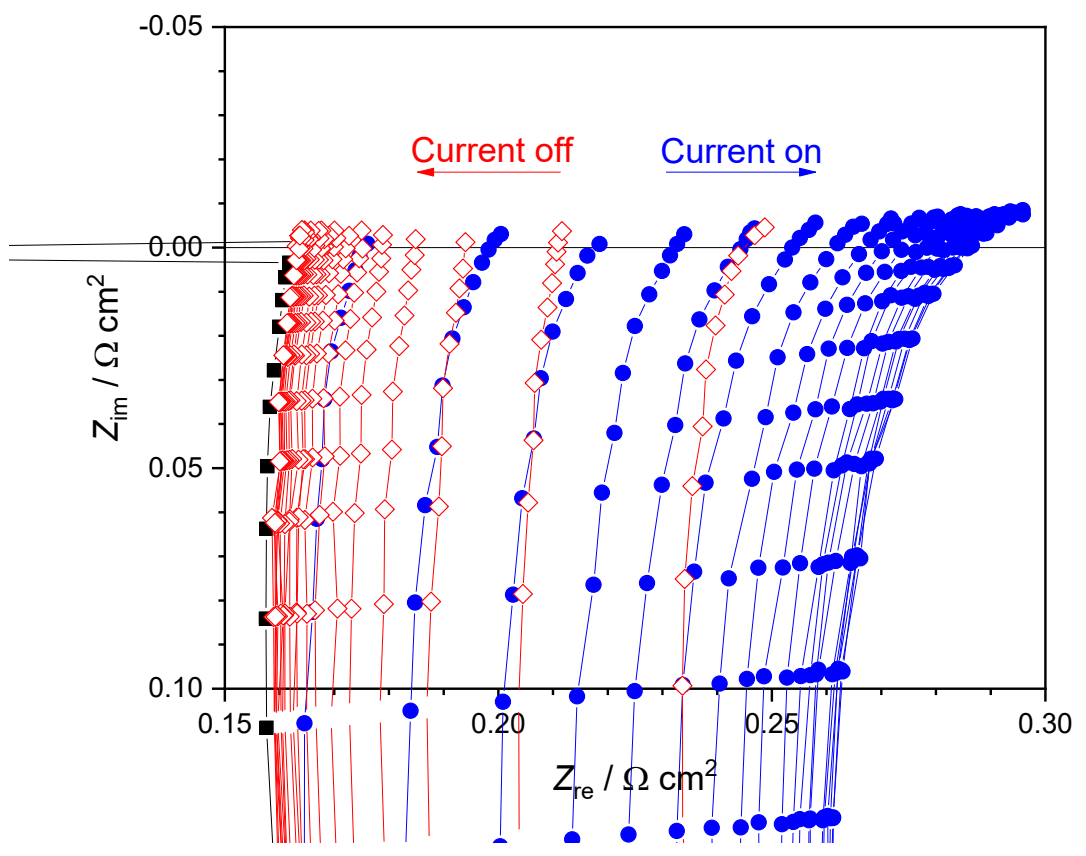

Figure 4 EIS spectra showing the change of the anode side membrane resistance when a direct current of $150 \mathrm{~mA} \mathrm{~cm}^{-2}$ was applied through the membrane and then stopped. The ADL of the PFSA membrane was $5.3 \mathrm{H}_{3} \mathrm{PO}_{4}$ per sulfonic acid group. The measurement was made at $160{ }^{\circ} \mathrm{C}$ under $p\left(\mathrm{H}_{2} \mathrm{O}\right)$ of $0.8 \mathrm{~atm}$. The duration of each cycle of the EIS measurement was $10.15 \mathrm{~s}$, which 
was followed immediately by another cycle. Markers: black filled squares prior to polarization, blue filled circles during polarization and unfilled diamonds during relaxation.

The resistance change relative to the open circuit resistance for a cell operating at $160^{\circ} \mathrm{C}$ with dry hydrogen (i.e. $p\left(\mathrm{H}_{2} \mathrm{O}\right)=0.0 \mathrm{~atm}$ ) on both sides is shown Figure 5a. Under dry atmosphere, the outermost layer membrane resistance, measured from A to B or C to D without applied current, was around $1.05 \Omega \mathrm{cm}^{2}$, corresponding to a conductivity of $6.7 \times 10^{-3} \mathrm{~S} \mathrm{~cm}^{-1}$. When a small anodic current density of $2.5 \mathrm{~mA} \mathrm{~cm}{ }^{-2}$ was applied, the resistance increased to a steady value of $1.16 \Omega$ $\mathrm{cm}^{2}$ within $400 \mathrm{~s}$. This resistance increased to $1.34 \Omega \mathrm{cm}^{2}$ when an anodic current density of $5 \mathrm{~mA}$ $\mathrm{cm}^{-2}$ was applied. When a negative current density was applied, the cathode membrane resistance was found to decrease, however, with a slightly smaller magnitude than the value of the anode membrane resistance increase. At a polarization current density of $5 \mathrm{~mA} \mathrm{~cm}{ }^{-2}$, the steady state cathode membrane resistance was decreased by $46 \mathrm{~m} \Omega \mathrm{cm}^{2}$, compared to the increase of $68 \mathrm{~m} \Omega$ $\mathrm{cm}^{2}$ for the anode membrane resistance. Figure 5a also shows that the initial anodic and cathodic resistances were restored $400 \mathrm{~s}$ after the applied current was turned off.

The ohmic resistance response to current changes for a corresponding cell based on a PA doped PBI membrane ${ }^{29}$ (see Scheme 1), is shown in Figure 5 b. The most notable observation is that the resistance response to the applied current in the PA doped PBI system was reversed compared to what was observed in the PA doped PFSA system. The anode side resistance was reduced by applying a positive current, while the resistance on the cathode side was increased when a negative current was applied. However, a significantly higher current density of $500 \mathrm{~mA}$ $\mathrm{cm}^{-2}$ was needed to induce similar resistance changes as induced by only 2.5 to $5 \mathrm{~mA} \mathrm{~cm}$ in the 
PFSA system. PA doped PBI has a transference number of only $1-4 \%$ for the $\mathrm{H}_{2} \mathrm{PO}_{4}{ }^{-}$anions, so the migration phenomenon in PFSA is taking place at a much higher scale than in PBI.

For both systems there is a small difference in the absolute values between the anodic resistance increase and cathodic resistance decrease, which can be explained by the fact that depletion and enrichment not necessarily give the same numerical change in conductivity. Moreover, the acid accumulated at the cathode side may diffuse into the electrode layer as well as gas channels..$^{50}$






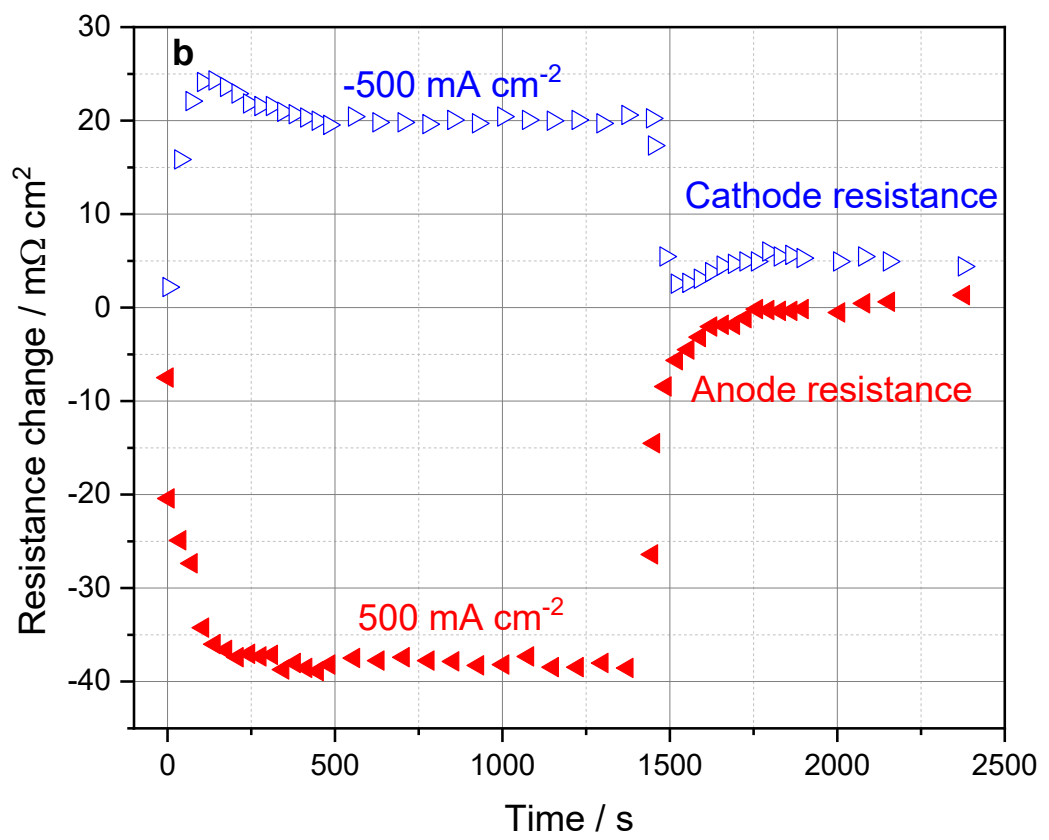

Figure 5 The membrane resistance changes at $160{ }^{\circ} \mathrm{C}$ under dry hydrogen flow at $p\left(\mathrm{H}_{2} \mathrm{O}\right)=0$ atm for a cell based on PFSA (a) and PBI (b) when an anodic or a cathodic current is applied at $t$ $=0 \mathrm{~s}$ and then stopped after around 400 and $1500 \mathrm{~s}$, respectively. Note the significant difference in current densities applied. The data for the PBI cell are taken from our previous work. ${ }^{29}$

It is obvious that the migration direction of the phosphoric oxoacid species is opposite in the two different electrolyte systems, and this is a consequence of the different ions formed by interaction with the polymer. In PBI, the imidazole moiety is protonated with formation of mobile $\mathrm{H}_{2} \mathrm{PO}_{4}{ }^{-}$. Vehicular transport towards the anode and recombination leads to accumulation of PA at the anode. In PFSA, the strong sulfonic acid protonates phosphoric acid and forms $\mathrm{H}_{4} \mathrm{PO}_{4}{ }^{+}$, which with opposite charge causes PA accumulation at the cathode. 
This can be explained by the fundamental acid-base chemistry of the species involved. As shown in Equation 2, nominally dry $\mathrm{H}_{3} \mathrm{PO}_{4}$ undergoes auto-protolysis with a degree of selfdissociation of about $5 \% .^{51}$

$2 \mathrm{H}_{3} \mathrm{PO}_{4} \rightleftarrows \mathrm{H}_{2} \mathrm{PO}_{4}^{-}+\mathrm{H}_{4} \mathrm{PO}_{4}^{+}$

The proton conductivity is dominated by the Grotthuss type structural diffusion with a cation transference number close to unity, ${ }^{19,}{ }^{21}$ i.e. intermolecular proton transfer that leads to proton transport over longer length scales. Only a few percent of the charge conduction involves migration of the ionic phosphoric oxoacid species. For 85 wt.\% aqueous $\mathrm{H}_{3} \mathrm{PO}_{4}$, which corresponds to the equimolar $\mathrm{H}_{3} \mathrm{PO}_{4} / \mathrm{H}_{2} \mathrm{O}$ composition, the structural diffusion transference number is decreased to about 0.15 at $60{ }^{\circ} \mathrm{C}^{20}$ In 73 wt.\% aqueous $\mathrm{H}_{3} \mathrm{PO}_{4}$, which corresponds to a $\mathrm{H}_{2} \mathrm{O} / \mathrm{H}_{3} \mathrm{PO}_{4}$ molar ratio of 2 and an equal number of proton donor and acceptor sites, the structural diffusion mechanism completely vanishes. ${ }^{23}$ The increasing contribution from vehicular migration with increasing water content is a consequence of the dissociation of $\mathrm{H}_{3} \mathrm{PO}_{4}$ in water, as shown in Equation 3.

$\mathrm{H}_{3} \mathrm{PO}_{4}+\mathrm{H}_{2} \mathrm{O} \rightleftarrows \mathrm{H}_{2} \mathrm{PO}_{4}^{-}+\mathrm{H}_{3} \mathrm{O}^{+}$

At concentrations higher than 100 wt. $\% \mathrm{H}_{3} \mathrm{PO}_{4}$, on the other hand, the acid condensation leads to formation of condensed phosphoric oxoacid species with increasing acidity, which promotes the protonation of $\mathrm{H}_{3} \mathrm{PO}_{4}$ to $\mathrm{H}_{4} \mathrm{PO}_{4}{ }^{+}$. The formation of monovalent condensate anions, e.g. $\mathrm{H}_{3} \mathrm{P}_{2} \mathrm{O}_{7}{ }^{-}$, has been proposed to occur primarily as follows: ${ }^{24}$ 
$2 \mathrm{H}_{3} \mathrm{PO}_{4} \rightleftarrows \mathrm{H}_{4} \mathrm{P}_{2} \mathrm{O}_{7}+\mathrm{H}_{2} \mathrm{O}$

$\mathrm{H}_{4} \mathrm{P}_{2} \mathrm{O}_{7}+\mathrm{H}_{3} \mathrm{PO}_{4} \rightleftarrows \mathrm{H}_{4} \mathrm{PO}_{4}^{+}+\mathrm{H}_{3} \mathrm{P}_{2} \mathrm{O}_{7}^{-}$

The acidity of these anions is, in fact, higher than or similar to that of the $\mathrm{H}_{3} \mathrm{PO}_{4}$ and the following reactions should be considered as recently suggested by Melchior et al..$^{23}$

$$
\begin{aligned}
& \mathrm{H}_{3} \mathrm{P}_{2} \mathrm{O}_{7}^{-}+\mathrm{H}_{3} \mathrm{PO}_{4} \rightleftarrows \mathrm{H}_{2} \mathrm{P}_{2} \mathrm{O}_{7}^{2-}+\mathrm{H}_{4} \mathrm{PO}_{4}^{+} \\
& \mathrm{H}_{4} \mathrm{P}_{3} \mathrm{O}_{10}{ }^{-}+\mathrm{H}_{3} \mathrm{PO}_{4} \rightleftarrows \mathrm{H}_{3} \mathrm{P}_{3} \mathrm{O}_{10}{ }^{2-}+\mathrm{H}_{4} \mathrm{PO}_{4}^{+}
\end{aligned}
$$

The evaporation of water shifts the equilibrium towards the condensed forms. The formation of $\mathrm{H}_{4} \mathrm{PO}_{4}{ }^{+}$cations and a variety of mono- and divalent $\mathrm{H}_{3} \mathrm{P}_{2} \mathrm{O}_{7}{ }^{-}, \mathrm{H}_{2} \mathrm{P}_{2} \mathrm{O}_{7}{ }^{2-}, \mathrm{H}_{4} \mathrm{P}_{3} \mathrm{O}_{10}{ }^{-}, \mathrm{H}_{3} \mathrm{P}_{3} \mathrm{O}_{10}{ }^{2-}$ anions under dry conditions leads to a significant contribution of the vehicular mechanism of the proton conductivity. As a result, the transference number of the structural diffusion in the high concentration range is considerably decreased, as the contribution from vehicular migration increases.

Similarly, dissolving the PA in an acidic (PFSA) or basic (PBI) polymer matrix environment should affect the condensation equilibrium of the PA within the membrane. As shown in Equation 8 and in Scheme 1 (bottom), the sulfonic acid groups are sufficiently acidic to protonate $\mathrm{H}_{3} \mathrm{PO}_{4}$ :

$\mathrm{R}-\mathrm{SO}_{3} \mathrm{H}+\mathrm{H}_{3} \mathrm{PO}_{4} \rightleftarrows \mathrm{R}-\mathrm{SO}_{3}{ }^{-}+\mathrm{H}_{4} \mathrm{PO}_{4}{ }^{+}$ 
It should be remarked that the $\mathrm{H}_{4} \mathrm{PO}_{4}{ }^{+}$cation has an estimated acid dissociation constant, expressed in its logarithmic form as $\mathrm{p} K_{\mathrm{a}} \approx-3,{ }^{52}$ while the hydronium cation $\mathrm{H}_{3} \mathrm{O}^{+}$has $\mathrm{p} K_{\mathrm{a}}$ of $-1.7 .^{53}$ The difference between the $\mathrm{p} K_{\mathrm{a}}$ of the proton acceptor and the donor, $\Delta \mathrm{p} K_{a}$ indicates the extent of proton transfer in acid-base reactions. The $\mathrm{R}-\mathrm{SO}_{3} \mathrm{H}$ group in PFSA membrane is known to be a super acid with $\mathrm{p} K_{\mathrm{a}}$ of -16 . This implies that, in the presence of free water which is a stronger base than PA, the formation of $\mathrm{H}_{4} \mathrm{PO}_{4}{ }^{+}$should be suppressed (Equation 9). Water is, indeed, generated at the cathode during fuel cell operation. However, the water generation rate is very low because of the low current density that the cell can support.

$$
\mathrm{H}_{4} \mathrm{PO}_{4}{ }^{+}+\mathrm{H}_{2} \mathrm{O} \rightleftarrows \mathrm{H}_{3} \mathrm{PO}_{4}+\mathrm{H}_{3} \mathrm{O}^{+}
$$

For the doping chemistry of PBI, the benzimidazole groups, a stronger base than water, will remain protonated as long as the $\mathrm{H}_{3} \mathrm{PO}_{4}$ concentration is sufficiently high to give a $\mathrm{pH}$ that is well below the $\mathrm{p} K_{\mathrm{a}}$ of the protonated PBI, which should be around 5.6. ${ }^{54}$ Thus, in the electrolyte system based on PA doped PBI membranes, PBI is quantitatively protonated by PA to form a protic polybenzimidazolium with phosphate counter anions, as shown in Equation 10 and Scheme 1. ${ }^{20,25}$

$$
\mathrm{H}_{3} \mathrm{PO}_{4}+\mathrm{PBI} \rightleftarrows \mathrm{H}_{2} \mathrm{PO}_{4}^{-}+\mathrm{PBI}-\mathrm{H}^{+}
$$

The $\mathrm{H}_{2} \mathrm{PO}_{4}{ }^{-}$anion is mobile and the contribution to the charge transport by $\mathrm{H}_{2} \mathrm{PO}_{4}{ }^{-}$migration and recombination with generated protons at the anode thus results in accumulation of PA at the anode (reduced resistance) and depletion at the cathode (increased resistance), as previously reported. ${ }^{29,}$ ${ }^{33}$ In the PA-PFSA system, on the other hand, the depletion of PA at the anode (increased 
resistance) and accumulation of PA at the cathode (reduced resistance) indicate migration of phosphoric oxoacid species in the opposite direction. This supports our previously reported hypothesis that the malfunction of the $\mathrm{H}_{3} \mathrm{PO}_{4}$ doped PFSA membranes is connected to migration of the phosphacidium cation $\left(\mathrm{H}_{4} \mathrm{PO}_{4}{ }^{+}\right)$towards the cathode. ${ }^{39}$

\subsection{Acid diffusion coefficient and cation transference number of $\mathrm{H}_{4} \mathrm{PO}_{4}{ }^{+}$}

Considering the ADL of the membrane of around $5 \mathrm{H}_{3} \mathrm{PO}_{4}$ molecules per sulfonic acid group, the fraction of protonated $\mathrm{H}_{3} \mathrm{PO}_{4}$ under anhydrous conditions (Equation 8), should be around $20 \%$. Hence, the promoted $\mathrm{H}_{4} \mathrm{PO}_{4}{ }^{+}$formation will affect the equilibria described by Equations (5-7) and thus the condensation of the PA (Equation 4).

As discussed in the previous section, the migration of $\mathrm{H}_{4} \mathrm{PO}_{4}{ }^{+}$cations from the anode to the cathode side is assumed to be the primary charge transport mechanism through the membrane. The processes at the anode and cathode can thus be described by Equation 11 and 12, respectively, as illustrated in Figure 6a. This is, however, a simplified view of the processes. It should be kept in mind that the hydrogen oxidation reaction at the anode occurs at the catalyst surface, followed by transfer of the protons to the $\mathrm{H}_{3} \mathrm{PO}_{4}$ carriers. Similarly, on the cathode side the protons from the proton carriers are transferred to the electrocatalytically active surfaces, where the hydrogen evolution reaction occurs.

$$
\begin{aligned}
& 1 / 2 \mathrm{H}_{2}+\mathrm{H}_{3} \mathrm{PO}_{4} \rightleftarrows \mathrm{H}_{4} \mathrm{PO}_{4}^{+}+\mathrm{e}^{-} \\
& \mathrm{H}_{4} \mathrm{PO}_{4}^{+}+\mathrm{e}^{-} \rightleftarrows 1 / 2 \mathrm{H}_{2}+\mathrm{H}_{3} \mathrm{PO}_{4}
\end{aligned}
$$



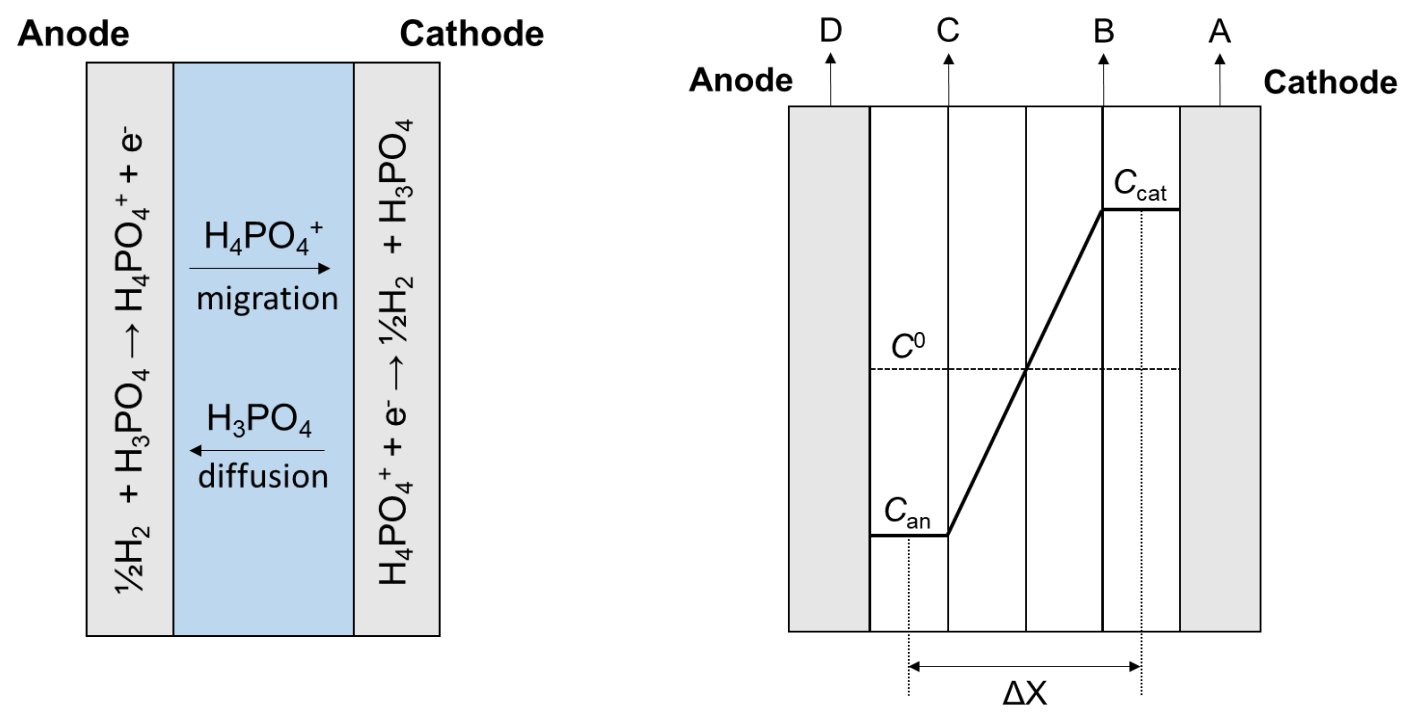

Figure 6 (a) Schematic illustration of the dynamics of the predominating phosphoric oxoacid species in a hydrogen pumping cell based on a PA doped PFSA membrane. (b) Schematic of the assumed PA concentration profile developed upon a constant current. A and D are the two gas diffusion electrodes, while $\mathrm{B}$ and $\mathrm{C}$ are the platinum micro reference electrodes. The ohmic resistance of the outermost layer membrane was measured between either A and B or C and D, i.e. including the gas diffusion electrode. The dashed line represents the initial acid concentration $C^{0}$ through the four layers of membranes. The steady state acid concentrations estimated from the ohmic measured resistance across the anode side and cathode side membrane, $C_{\text {an }}$ and $C_{\text {cat }}$, respectively, are taken as an average value through the layer thickness $\Delta \mathrm{X}$.

The developed PA concentration difference across the membrane, as illustrated in Figure 6b, is a result of the balanced $\mathrm{H}_{4} \mathrm{PO}_{4}{ }^{+}$migration towards the cathode and the concentration gradient driven back-diffusion towards the anode. The process can be described by the following equation (with all terms as positive quantities) : 
$\frac{\mathrm{d} C_{\mathrm{H}_{3} \mathrm{PO}_{4}}}{\mathrm{~d} t} \cdot \Delta X=J_{\text {Migration }}-J_{\text {Diffusion }}$

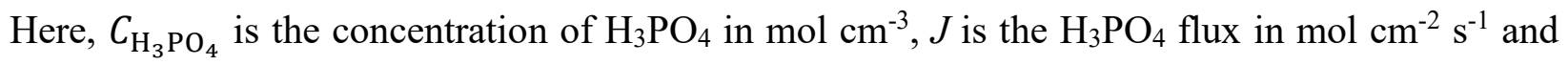
$\Delta X$ is the back diffusion distance of $\mathrm{H}_{3} \mathrm{PO}_{4}$ (taken as $210 \mu \mathrm{m}$ in the present study). The ionic migration is calculated by the fraction of the total current density that is due to $\mathrm{H}_{4} \mathrm{PO}_{4}{ }^{+}$migration, i.e. the product of the current density and the transference number $t_{\mathrm{H}_{4} \mathrm{PO}_{4}^{+}}$, following Faraday's law:

$J_{\text {Migration }}=\frac{i \cdot t_{\mathrm{H}_{4} \mathrm{PO}_{4}^{+}}}{F}$

The process of back diffusion of $\mathrm{H}_{3} \mathrm{PO}_{4}$ can be described by Fick's Law:

$J_{\text {Diffusion }}=D \cdot \frac{\Delta C_{\mathrm{H}_{3} \mathrm{PO}_{4}}}{\Delta X}$

Here, $D$ is the effective diffusion coefficient of PA though the membrane and $\Delta C_{\mathrm{H}_{3} \mathrm{PO}_{4}}$ is the concentration difference across the membrane.

In order to correlate the measured resistance changes with the PA balance, the relationship of the conductivity with the PA content and its molar concentration in the polymer membrane phase was defined. An average PA concentration in the cathode and anode layer membrane, $C_{\text {cat }}$ and $C_{\text {an, }}$ was obtained from the measured membrane resistance change using the calibration curves of the ionic conductivity and swollen membrane volume versus the ADL, as shown in Figure 7a. The gradient is defined as the difference between $C_{\text {cathode }}$ and $C_{\text {anode }}$ across the thickness of the 
diffusing layer $\Delta X$. At lower ADLs, the loss of percolation results in a significant conductivity drop as also suggested by simulations. ${ }^{41}$ The steps to calculate the corresponding diffusion coefficient and transference number are described in our previous work. ${ }^{29}$

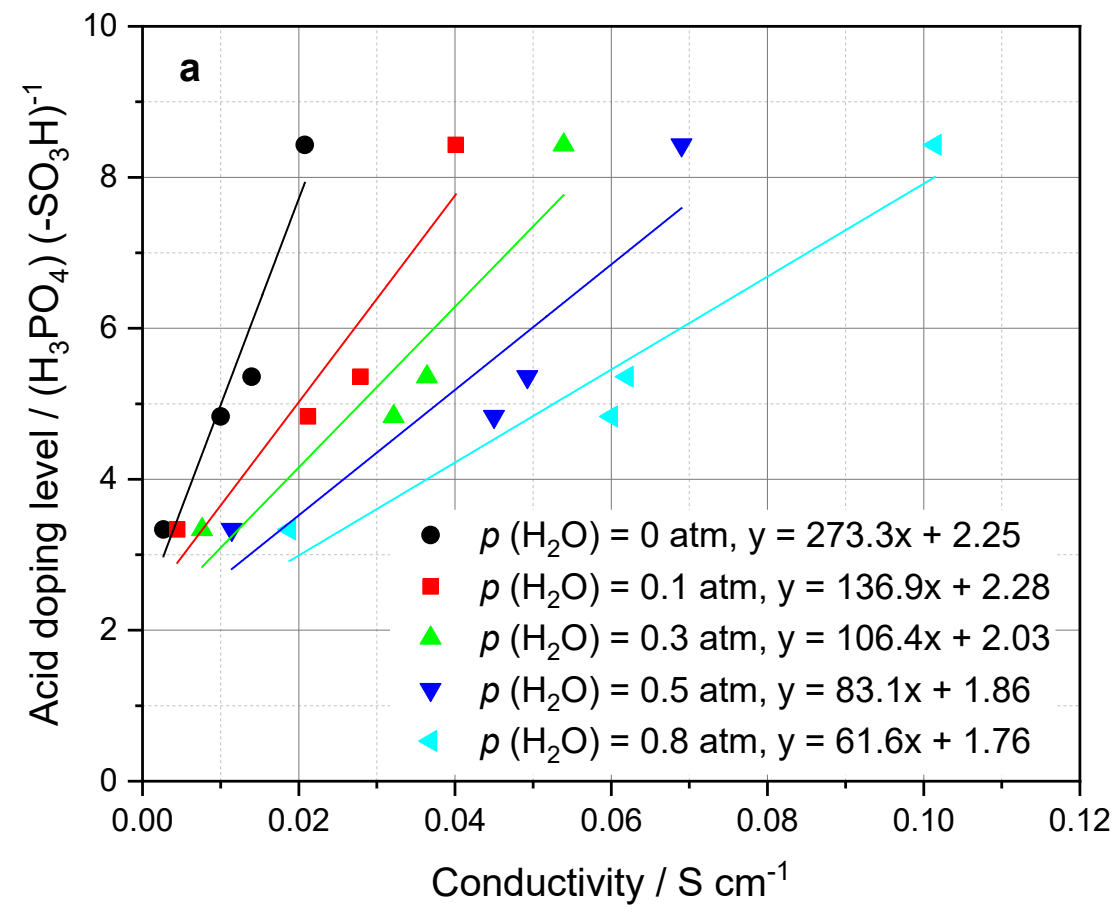




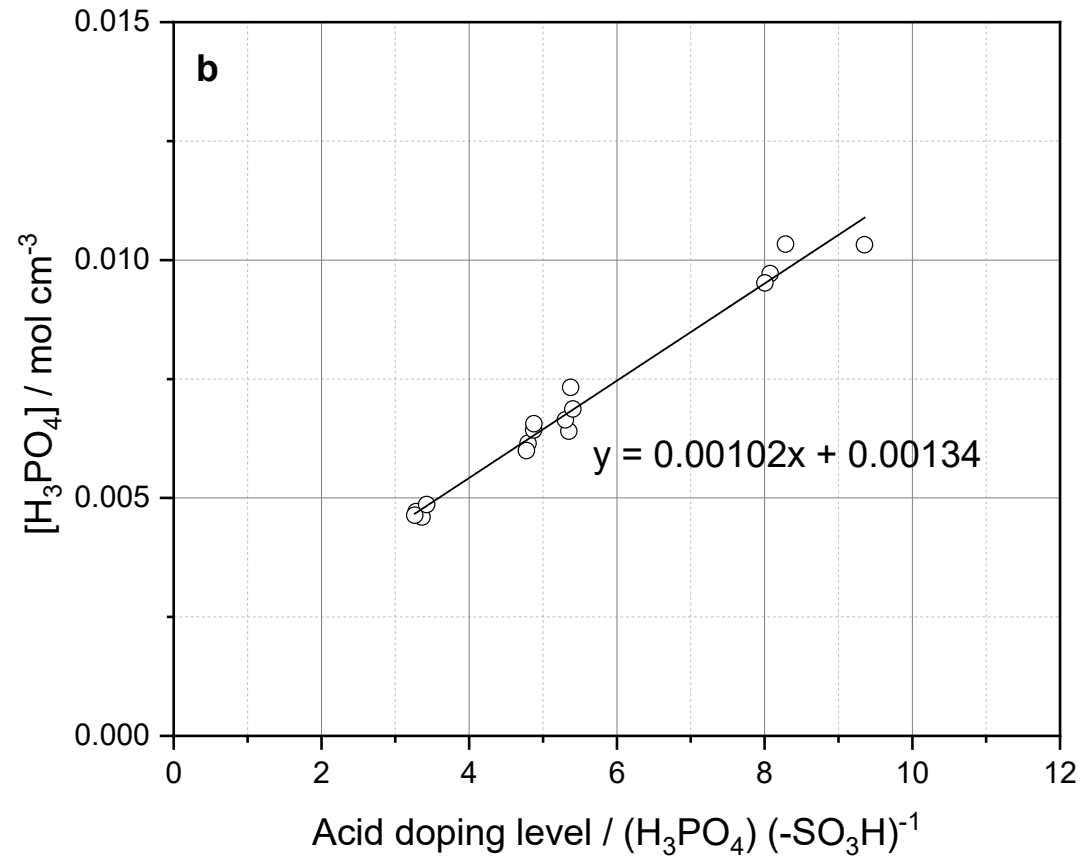

Figure 7 Calibration curves of acid doping level versus conductivity (a) and acid doping level versus acid concentration in doping solution (b).

The correlation between ADL and the molar concentration of $\mathrm{H}_{3} \mathrm{PO}_{4}$ within the membrane, calculated based on the weight fraction of $\mathrm{H}_{3} \mathrm{PO}_{4}$ and the swelling after doping, is shown in Figure 7b. The constants from the linear fits in Figure $7 \mathrm{a}$ and $7 \mathrm{~b}$ are summarized in Table 2, and were used for used for the further calculations

Table 2 Calculated PA diffusion coefficients and $\mathrm{H}_{4} \mathrm{PO}_{4}{ }^{+}$cation transference numbers.

\begin{tabular}{lccccc}
\hline$p\left(\mathrm{H}_{2} \mathrm{O}\right) / \mathrm{atm}$ & 0.0 & 0.1 & 0.3 & 0.5 & 0.8 \\
\hline $\mathrm{D}\left(\mathrm{m}^{2} \mathrm{~s}^{-1}\right) \times 10^{10}$ & 0.75 & 1.7 & 2.1 & 1.8 & 1.8 \\
$\mathrm{t}_{\mathrm{H}_{4} \mathrm{PO}_{4}^{+}}$ & 0.52 & 0.43 & 0.31 & 0.20 & 0.09 \\
\hline
\end{tabular}


A series of resistance determinations were conducted at $160{ }^{\circ} \mathrm{C}$ at different water partial pressures during on/off cycling of anodic (positive) and cathodic (negative) current density. The applied current density varied from 2.5 and $5 \mathrm{~mA} \mathrm{~cm}^{-2}$ for dry hydrogen to $150-200 \mathrm{~mA} \mathrm{~cm}^{-2}$ at relatively high water vapor pressures. The calculated PA diffusion coefficients and $\mathrm{H}_{4} \mathrm{PO}_{4}{ }^{+}$cation transference numbers are summarized in Table 2 and also shown in Figures $8 \mathrm{a}$ and $8 \mathrm{~b}$, respectively, as a function of the water partial pressure at a constant temperature of $160^{\circ} \mathrm{C}$.

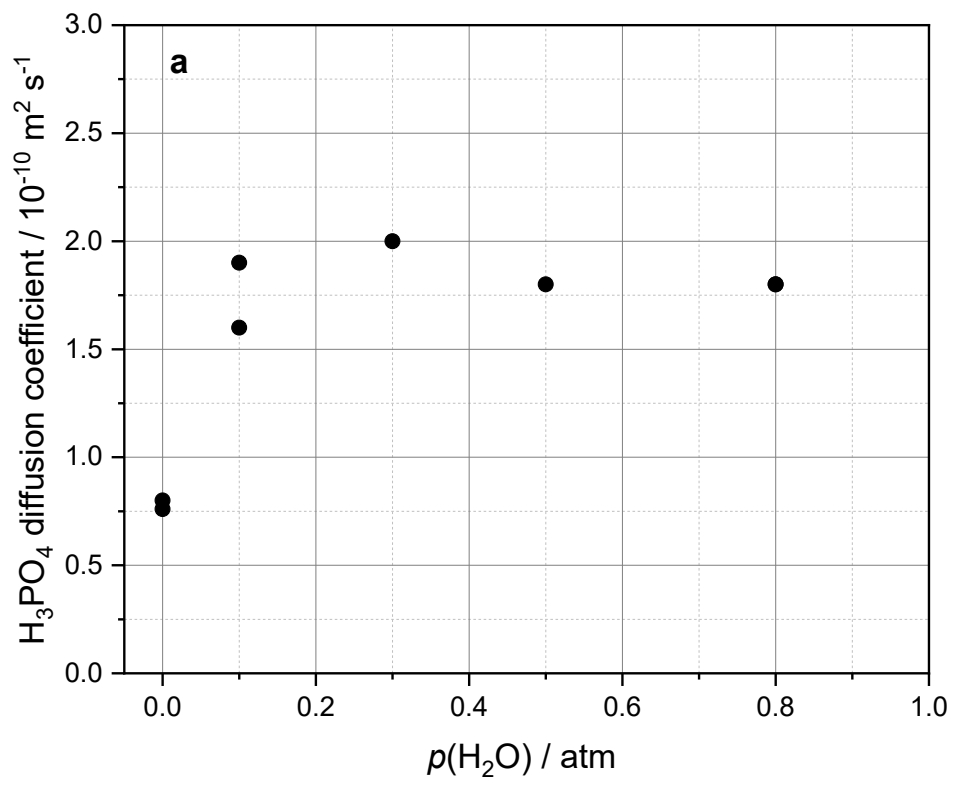




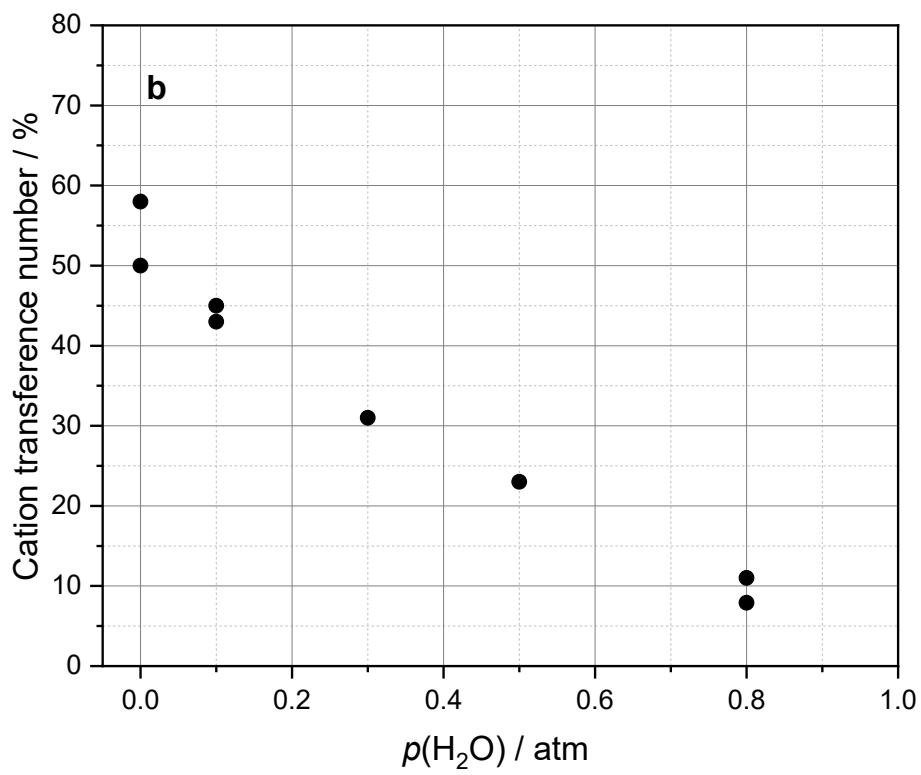

Figure $8 \mathrm{H}_{3} \mathrm{PO}_{4}$ diffusion coefficient (a) and $\mathrm{H}_{4} \mathrm{PO}_{4}{ }^{+}$transference number (b) for $\mathrm{PA}$ acid doped Aquivion membranes as a function of water partial pressure at $160{ }^{\circ} \mathrm{C}$.

It is clearly seen that the $\mathrm{H}_{3} \mathrm{PO}_{4}$ diffusion coefficient increased when the water partial pressure increased up to $0.3 \mathrm{~atm}$. Under dry hydrogen atmosphere, the diffusion coefficient was $7.8 \times 10^{-11}$ $\mathrm{m}^{2} \mathrm{~s}^{-1}$, which increased to $1.7 \times 10^{-10} \mathrm{~m}^{2} \mathrm{~s}^{-1}$ at water partial pressure of $0.1 \mathrm{~atm}$. These values are almost double those in PA doped PBI membranes. ${ }^{29}$ Further increasing the water partial pressure from 0.1 to 0.8 atm did not seem to lead to a changed diffusion coefficient.

The diffusion coefficients were then used to calculate the transference number of the monovalent cation $\left(t_{\mathrm{H}_{4} \mathrm{PO}_{4}^{+}}\right)$. Under dry hydrogen atmosphere, the $\mathrm{H}_{4} \mathrm{PO}_{4}{ }^{+}$transference number is as high as $52 \%$. Due to the absence of water, the interaction between the PFSA and $\mathrm{H}_{3} \mathrm{PO}_{4}$ leads to complete transfer of protons and therefore formation of immobilized sulfonate anions $\left(\mathrm{R}-\mathrm{SO}_{3}{ }^{-}\right)$ and the $\mathrm{H}_{4} \mathrm{PO}_{4}{ }^{+}$cations, which are mobile in the excess $\mathrm{H}_{3} \mathrm{PO}_{4}$. The highly ionic characteristics of the interactions, with complete transfer of protons from the sulfonic acid to $\mathrm{H}_{3} \mathrm{PO}_{4}$, may limit the 
extensive and polarizable hydrogen bond network, which is necessary for the intermolecular proton transfer via the structural diffusion mechanism. This may explain the extremely high cation transference number of the membrane. Furthermore, the PA condensation and the $\mathrm{H}_{4} \mathrm{PO}_{4}{ }^{+}$ formation lead to a significant reduction of the number of hydrogen bond acceptors, which likely contributes to further suppressing the Grotthuss-type structural diffusion mechanism. ${ }^{19}$

When water is present in the atmosphere, the protonation of $\mathrm{H}_{3} \mathrm{PO}_{4}$ is suppressed and protonation of water is promoted. As a general fact, any stronger acids in an aqueous solution would steadily dissociate and end up in the formation of $\mathrm{H}_{3} \mathrm{O}^{+}$of $\mathrm{p} K_{\mathrm{a}}=-1.74$, a much less acidic species than $\mathrm{H}_{4} \mathrm{PO}_{4}{ }^{+}$. As a result, the transference number of the $\mathrm{H}_{4} \mathrm{PO}_{4}^{+}$cation is steadily decreased with the water partial pressure, down to less than $10 \%$ at water vapor pressures of 0.8 atm, as seen from Figure $8 b$.

It is of note that the present measurement of the $\mathrm{H}_{4} \mathrm{PO}_{4}{ }^{+}$transference number has not taken into account the contribution of $\mathrm{H}_{3} \mathrm{O}^{+}$. For pristine PFSA membranes in the hydrated form, a significant electroosmotic water drag coefficient of 2.5-3.0 $\mathrm{H}_{2} \mathrm{O} / \mathrm{H}^{+}$has been reported. ${ }^{55,56}$ Molecular water has a somewhat high diffusion coefficient in PFSA membranes, in the range of $10^{-8}-10^{-5} \mathrm{~cm}^{2} \mathrm{~s}^{-1}$ depending on the water content. ${ }^{44}$ As a comparison, the diffusion of PA acid in the PFSA membrane is 2-5 orders of magnitude slower. The slow back-diffusion of acid molecules to the anode is, therefore, assumed as the main reason for the charge carrier starvation at the anode and gives rise to the limiting current density. The limiting current density is significantly smaller under the dry conditions when the acid cation transference number is about 5 times larger, while the acid molecular diffusion coefficient is 2 times lower. 


\section{Conclusions}

Phosphoric acid doped perfluorosulfonic acid membranes exhibit high proton conductivity at elevated temperatures, but fail to support higher currents than a few $\mathrm{mA} \mathrm{cm}{ }^{-2}$. When operated in hydrogen pumping or fuel cell mode, the malfunction at higher currents is due to migration of the $\mathrm{H}_{4} \mathrm{PO}_{4}{ }^{+}$cation towards the cathode. The $\mathrm{H}_{3} \mathrm{PO}_{4}$ diffusion coefficient in the PFSA membrane was found to be 5-6 orders of magnitude lower than that of water. The slow back-diffusion of $\mathrm{H}_{3} \mathrm{PO}_{4}$ thus leads to $\mathrm{H}_{3} \mathrm{PO}_{4}$ depletion at the anode-membrane interface and a dramatic increase of the ohmic resistance. The $\mathrm{H}_{4} \mathrm{PO}_{4}{ }^{+}$formation is promoted by the strongly acidic environment within the perfluorosulfonic acid membranes, which lead to a $\mathrm{H}_{4} \mathrm{PO}_{4}{ }^{+}$transference of as high as $52 \%$ under dry conditions at $160{ }^{\circ} \mathrm{C}$. The phenomenon is mitigated as the water vapor pressure is increased, which suppresses the protonation of phosphoric acid. It also explains why phosphoric acid doped perfluorosulfonic acid membranes work well in water electrolysis mode, when the water activity is high. The reported findings bring insight into the importance of tailoring the acidbase chemistry in high-temperature polymer electrolyte membranes and its significance for the proton conductivity mechanism.

\section{Acknowledgement}

This work was financially supported by the European Union's Horizon 2020 research and innovation program under the grant agreement no. 761093, project LOTER.CO2M. 


\section{References}

1. J. S. Wainright, J. T. Wang, D. Weng, R. F. Savinell, and M. Litt, J. Electrochem. Soc., 142, L121 (1995).

2. Q. Li, R. He, J. O. Jensen, and N. J. Bjerrum, Chem. Mater., 15, 4896 (2003).

3. Q. Li, J. O. Jensen, R. F. Savinell, and N. J. Bjerrum, Prog. Polym. Sci., 34, 449 (2009).

4. A. Chandan, M. Hattenberger, A. El-Kharouf, S. F. Du, A. Dhir, V. Self, B. G. Pollet, A. Ingram, and W. Bujalski, J. Power Sources, 231264 (2013).

5. S. S. Araya, F. Zhou, V. Liso, S. L. Sahlin, J. R. Vang, S. Thomas, X. Gao, C. Jeppesen, and S. K. Kær, Int. J. Hydrogen Energy, 41, 21310 (2016).

6. D. Aili, D. Henkensmeier, S. Martin, B. Singh, Y. Hu, J. O. Jensen, L. N. Cleemann, and Q. Li, Electrochem. Energy Rev., Submitted (2020).

7. S. Martin, P. L. Garcia-Ybarra, and J. L. Castillo, Electrochem. Commun., 93, 57 (2018).

8. S. Martin, J. O. Jensen, Q. Li, P. L. Garcia-Ybarra, and J. L. Castillo, Int. J. Hydrogen Energy, 44, 28273 (2019).

9. T. Søndergaard, L. N. Cleemann, H. Becker, D. Aili, T. Steenberg, H. A. Hjuler, L. Seerup, Q. Li, and J. O. Jensen, J. Power Sources, 342570 (2017).

10. A. T. Pingitore, F. Huang, G. Qian, and B. C. Benicewicz, ACS Appl. Energy Mater., 2, 1720 (2019).

11. D. Aili, J. Zhang, M. T. Dalsgaard Jakobsen, H. Zhu, T. Yang, J. Liu, M. Forsyth, C. Pan, J. O. Jensen, L. N. Cleemann, S. P. Jiang, and Q. Li, J. Mater. Chem. A, 4, 4019 (2016).

12. J. Zhang, D. Aili, J. Bradley, H. Kuang, C. Pan, R. De Marco, Q. Li, and S. P. Jiang, J. Electrochem. Soc., 164, F1615 (2017). 
13. Y. Cheng, J. Zhang, S. Lu, H. Kuang, J. Bradley, R. De Marco, D. Aili, Q. Li, C. Q. Cui, and S. P. Jiang, Int. J. Hydrogen Energy, 43, 22487 (2018).

14. D. Aili, J. Yang, K. Jankova, D. Henkensmeier, and Q. Li, J. Mater. Chem. A, DOI: 10.1039/d0ta01788d (2020).

15. D. Aili, L. N. Cleemann, Q. Li, J. O. Jensen, E. Christensen, and N. J. Bjerrum, J. Mater. Chem., 22, 5444 (2012).

16. J. Yang, L. N. Cleemann, T. Steenberg, C. Terkelsen, Q. Li, J. O. Jensen, H. A. Hjuler, N. J. Bjerrum, and R. He, Fuel Cells, 14, 7 (2014).

17. L. X. Xiao, H. F. Zhang, E. Scanlon, L. S. Ramanathan, E. W. Choe, D. Rogers, T. Apple, and B. C. Benicewicz, Chem. Mater., 17, 5328 (2005).

18. A. Kirkebæk, D. Aili, D. Henkensmeier, J. O. Jensen, and Q. Li, Macromol. Mater. Eng., 1700347 (2017).

19. L. Vilčiauskas, M. E. Tuckerman, G. Bester, S. J. Paddison, and K.-D. Kreuer, Nat. Chem., 4, 461 (2012).

20. J.-P. Melchior, G. Majer, and K.-D. Kreuer, Phys. Chem. Chem. Phys., 19, 601 (2017).

21. T. Dippel, K.-D. Kreuer, J. C. Lassègues, and D. Rodriguez, Solid State Ionics, 61, 41 (1993).

22. Y. Aihara, A. Sonai, M. Hattori, and K. Hayamizu, J. Phys. Chem. B, 110, 24999 (2006).

23. J.-P. Melchior, K.-D. Kreuer, and J. Maier, Phys. Chem. Chem. Phys., 19, 587 (2017).

24. R. A. Munson and M. E. Lazarus, J. Phys. Chem., 71, 3245 (1967).

25. C. E. Hughes, S. Haufe, B. Angerstein, R. Kalim, U. Mahr, A. Reiche, and M. Baldus, J. Phys. Chem. B, 108, 13626 (2004). 
26. F. Conti, A. Majerus, V. Di Noto, C. Korte, W. Lehnert, and D. Stolten, Phys. Chem. Chem. Phys., 14, 10022 (2012).

27. G. A. Giffin, F. Conti, S. Lavina, A. Majerus, G. Pace, C. Korte, W. Lehnert, and V. Di Noto, Int. J. Hydrogen Energy, 39, 2776 (2014).

28. R. Bouchet and E. Siebert, Solid State Ionics, 118, 287 (1999).

29. H. Becker, U. Reimer, D. Aili, L. N. Cleemann, J. O. Jensen, W. Lehnert, and Q. Li, J. Electrochem. Soc., 165, F863 (2018).

30. T. Arlt, W. Maier, C. Tötzke, C. Wannek, H. Markötter, F. Wieder, J. Banhart, W. Lehnert, and I. Manke, J. Power Sources, 246, 290 (2014).

31. S. H. Eberhardt, M. Toulec, F. Marone, M. Stampanoni, F. N. Büchi, and T. J. Schmidt, J. Electrochem. Soc., 162, F310 (2015).

32. S. H. Eberhardt, F. Marone, M. Stampanoni, F. N. Buchi, and T. J. Schmidt, J. Electrochem. Soc., 163, F842 (2016).

33. H. Becker, L. N. Cleemann, D. Aili, J. O. Jensen, and Q. Li, Electrochem. Commun., 82 $21(2017)$.

34. R. Savinell, E. Yeager, D. Tryk, U. Landau, J. Wainright, D. Weng, K. Lux, M. Litt, and C. Rogers, J. Electrochem. Soc., 141, L46 (1994).

35. D. Aili, M. K. Hansen, C. Pan, Q. Li, E. Christensen, J. O. Jensen, and N. J. Bjerrum, Int. J. Hydrogen Energy, 36, 6985 (2011).

36. M. K. Hansen, D. Aili, E. Christensen, C. Pan, S. Eriksen, J. O. Jensen, J. H. von Barner, Q. Li, and N. J. Bjerrum, Int. J. Hydrogen Energy, 37, 10992 (2012).

37. J. Xu, Q. Li, M. K. Hansen, E. Christensen, A. L. T. García, G. Liu, X. Wang, and N. J. Bjerrum, Int. J. Hydrogen Energy, 37, 18629 (2012). 
38. J. Xu, D. Aili, Q. Li, E. Christensen, J. O. Jensen, W. Zhang, M. K. Hansen, G. Liu, X. Wang, and N. J. Bjerrum, Energy Environ. Sci., 7, 820 (2014).

39. D. Aili, R. F. Savinell, J. O. Jensen, L. N. Cleemann, N. J. Bjerrum, and Q. Li, ChemElectroChem, 1, 1471 (2014).

40. R. Kotz, S. Clouser, S. Sarangapani, and E. Yeager, J. Electrochem. Soc., 131, 1097 (1984).

41. L. Yan, S. Zhu, X. Ji, and W. Lu, J. Phys. Chem. B, 111, 6357 (2007).

42. A. M. Petrascu, M. H. J. Koch, and A. Gabriel, J. Macromol. Sci. Part B: Phys., B37, 463 (1998).

43. S. Wasmus, A. Valeriu, G. D. Mateescu, D. A. Tryk, and R. F. Savinell, Solid State Ionics, 80, 87 (1995).

44. K.-D. Kreuer, M. Schuster, B. Obliers, O. Diat, U. Traub, A. Fuchs, U. Klock, S. J. Paddison, and J. Maier, J. Power Sources, 178, 499 (2008).

45. K.-D. Kreuer, Chem. Mater., 26, 361 (2014).

46. K.-D. Kreuer and G. Portale, Adv. Funct. Mater., 23, 5390 (2013).

47. D. Aili, M. K. Hansen, J. W. Andreasen, J. Zhang, J. O. Jensen, N. J. Bjerrum, and Q. Li, J. Membr. Sci., 493589 (2015).

48. K. Schmidt-Rohr and Q. Chen, Nat. Mater., 7, 75 (2008).

49. D. W. M. Hofmann, L. Kuleshova, B. D'Aguanno, V. Di Noto, E. Negro, F. Conti, and M. Vittadello, J. Phys. Chem. B, 113, 632 (2009).

50. J. Halter, F. Marone, T. J. Schmidt, and F. N. Büchi, J. Electrochem. Soc., 165, F1176 (2018).

51. R. A. Munson, J. Phys. Chem., 68, 3374 (1964). 
52. C. Korte, F. Conti, J. Wackerl, and W. Lehnert, in High Temperature Polymer Electrolyte Membrane Fuel Cells, Q. Li, D. Aili, H. A. Hjuler and J. O. Jensen, eds., p. 169, Springer, New York (2016).

53. T. Ikeda, K. Saito, R. Hasegawa, and H. Ishikita, Angew. Chem. Int. Ed., 56, 9151 (2017).

54. H. Walba and R. W. Isensee, J. Org. Chem., 26, 2789 (1961).

55. T. A. Zawodzinski, C. Derouin, S. Radzinski, R. J. Sherman, V. T. Smith, T. E. Springer, and S. Gottesfeld, J. Electrochem. Soc., 140, 1041 (1993).

56. G. Xie and T. Okada, J. Electrochem. Soc., 142, 3057 (1995). 